\title{
Erratum to: Sign o' the Times: Does Francis' Papacy Represent a New Era for Western Europe?
}

\author{
Elizabeth Carter
}

Erratum to:

Chapter 9 in: A. J. Lyon et al. (eds.), Pope Francis as a Global Actor, Palgrave Studies in Religion, Politics, and Policy, https://doi. org/10.1007/978-3-319-71377-9_9

The original version of Chapter 9 was inadvertently published with incorrect chapter title “The Pope and Europe: Sign o' the Times: Does Pope Francis's Papacy Represent a New Era for Western Europe?” instead of “Sign o' the Times: Does Francis' Papacy Represent a New Era for Western Europe?". The chapter has been updated.

The updated online version of this chapter can be found at https://doi.org/10.1007/978-3-319-71377-9_9

(C) The Author(s) 2018

E1

A. J. Lyon et al. (eds.), Pope Francis as a Global Actor, Palgrave Studies in Religion, Politics, and Policy, https://doi.org/10.1007/978-3-319-71377-9_14 